\title{
Nexus between Education and Poverty in Africa: Evidence from Sierra Leone
}

\author{
Sheka Bangura ${ }^{1,2}$, Sangho Kim ${ }^{3, *}$ \\ ${ }^{1}$ Central Planning, Monitoring and Evaluation in the Ministry of Finance and Economic Development in Freetown, Sierra Leone \\ ${ }^{2}$ University of Makeni, Makeni, Sierra Leone \\ ${ }^{3}$ College of International Management, Ritsumeikan Asia Pacific University, Ritsumeikan Asia Pacific University, 1-1 Jumonjibaru, \\ Beppu, Oita 974-8577, Japan
}

Copyright $(\mathrm{C} 2017$ by authors, all rights reserved. Authors agree that this article remains permanently open access under the terms of the Creative Commons Attribution License 4.0 International License

\begin{abstract}
We have discovered education as a lead predictor of poverty in Sub-Saharan Africa with evidence from Sierra Leone based on the country's integrated household survey 2011. Noticeably, education expenditure could have negative direct impact on welfare in the short run even though it delivers long run positive effect through indirect effect of covariates. This explains an inevitability of policy trade-offs with the simultaneous decision making problems a poor household faces, which would sometimes have to reduce health spending in favour of child education. Thus, careful policy is critical to ensuring optimal balance of effects on general household welfare that derive from household decision making problems.
\end{abstract}

Keywords Education, Poverty, Health, Sierra Leone, Africa

JEL Classification Codes: I21; I32; 055

\section{Introduction}

There is vast scholarly literature suggesting that education is the most essential correlate of poverty and human development (Becker 1960; Collier 2007; Grossman 2000; Mackinnon 1995; Romer 1993; Sen 1993; Solow 1956). Some societies have increased the wellbeing of their populations with increased levels of schooling at relatively low income, thus placing literacy atop in pursuing welfare objectives (Grossman 2000; Mackinnon 1995; UNDP 2010; Wagle 2010).

The knock-on-effects of education on other sectors are enormous. For instance, fertility rates can be managed better in societies with high literacy rates, and graduates with just basic education in the rural areas can boast of minimum knowledge necessary to significantly impact on agricultural productivity (Acker and Gasperini 2003). Additionally, literacy can engender efficient rural-urban migration, and can drastically stem bad governance plaguing a pool of countries in the bottom billion of the world (Collier 2007; among others). The resource-curse hypothesis - which explains the persistence of poverty, economic downturns and conflicts amidst abundant natural resources in least developed countries - heavily reflects the expected correlation between widespread illiteracy and weak state governance (Collier 2007; Koning 2008; Sachs and Warner 2001). An enlightened citizenry would engender the desired leadership in societies and hence the right institutions. It induces policies and political restraints necessary to enforce social accountability in public service delivery, and thereby effectively reducing poverty and maximizing the chances of achieving sustainable growth and development.

Literacy is a lead yardstick in the United Nations' assessment and comparison of development performance across countries. The United Nations Millennium Development Goals (UN MDGs) and Poverty Reduction Strategy Papers of the IMF and the World Bank have been popular amongst the international development policy frameworks that prioritise literacy for poor countries. Unfortunately, nations have continued to witness high rates of illiteracy and endemic poverty, which is most phenomenal in Sub-Saharan Africa (SSA). In SSA, about 50 percent of the region's population is still rated poor at an expenditure benchmark of US\$ 1.25 a day, which increases to 70 percent if a benchmark of US\$ 2 per day is used; and 36 out of the 50 poorest countries in the world are located in SSA (Bangura 2015, p.21). A number of Sub-Saharan African countries have not made much progress on the Millennium Development Goals in fighting poverty; real poverty has doubled since 1981 (Chen and Ravallion 2008).

The fact that a great number of African countries are endowed with abundant natural resources yet many of them have lagged behind natural resource-barren regions, suggests a great need for improvement in the knowledge base of the continent. Special emphases are needed to improve education in the rural areas which at the global level hold more than 70 percent of the poor. Improving the knowledge 
system of Africa is all the more critical to resolving the arguments over the relevance of foreign direct investment in growth-constrained nations. From the perspective of many development scholars, trade is still alive as inevitable instrument for countries to break out of poverty, but gaining effective foothold in this instrument would require massive investment in education.

Given the generally poignant policy outcomes in a range of African countries, it is vital from the standpoint of the role of human capital in development that policy is adequately informed through a robust investigation of the key determinants of education.

This study therefore analyses the relevance of education to poverty reduction in SSA with evidence from one of the least developed countries, Sierra Leone, based on its integrated household survey 2011. The analysis is carried out within the human capital investment models with the employment of two-level structural simultaneous equation estimations. On the first level, we conduct a three-stage least squares (3SLS) where we look at the interaction of income poverty not only with education as a crucial component of human capital for poverty reduction, but also health investment as another key human capital component. Precisely, we recursively run three-equation 3SLS functions on this level: household income consumption; investment in child education; and investment in household health. On the second level, we estimate a two-equation simultaneous system with poverty headcount ratio as a dichotomous endogenous variable and years of schooling of household head as a continuous endogenous variable within a two-stage probit least squares framework that enable us to predict poverty reduction or increase with education and other household socio-economic conditions.

A key contribution of this paper is the accentuation of the need to prioritise education as the most fundamental poverty reduction instrument with vivid implication for micro and macro level policy developments. It suggests the need to ensure optimal balance in the national distribution of resources across socio-economic sectors as these sectors do reinforce each other in reducing poverty or counteract themselves at the expense of widening poverty at the poor household decision making level if balanced resource distribution is not ensured at national level. The paper discovers an inevitability of welfare trade-offs with the simultaneous decision making problems the average Sierra Leonean household faces: sometimes it may have to reduce health spending in favour of child education, for instance, and vice versa. Under these circumstances, managing fertility rates and population is crucial for sustainable poverty reduction.

The next section provides a brief literature on human capital and its relevance and looks at historical and current context of education and poverty in Sierra Leone. Section 3 presents the empirical model drawn from theory and previous empirical analysis. Section 4 presents estimated results along with data and variables. The final section discusses major findings and concludes the paper.

\section{Literature Survey}

\subsection{Nexus between Education and Poverty}

The nexus between education and poverty can best be conceptualised within the theoretical framework of the human capital models. There have been enormous scholarly efforts in building and discussing such models (Becker 1960; Grossman 2000; Grossman and Kaestner 1997; Heckman et al. 2003; Mincer 1958). In this literature, sustained human capital investment is widely argued to be the first rung in meaningfully fighting poverty. At the household level, this should be part of the overall planning of an individual's life time from the life-cycle human capital model perspective (Grossman 2000); at the state level, this is critical from the standpoint of ensuring sound macroeconomic growth and sustainable development (Aguayo et al. 2003; Walraven 2011).

Human capital is multifaceted, with knowledge acquisition the foremost for poverty reduction. It is argued human capital for poverty reduction can only be conceptualised with completeness if such other components as the stock of health and nutritional status are introduced in the analysis (Sahn and Stifel 2003; Shaffer 2008; Wagle 2010). In this regard, Wagle suggests a multidimensional approach to understanding household poverty by applying a non-recursive simultaneous equation estimation of five poverty functions to Nepal and USA. Carrying out estimation at latent factor level, his system consists of five functions: household economic wellbeing (including income and other measures); household capability (including education attainment and other measures); economic inclusion; political inclusion; and civic/cultural inclusion.

Indeed, education, estimated as a key poverty variable in previous studies, is interwoven with other forms of human capitals like health and the traditional welfare measures of income/expenditure in determining levels of poverty.

Since the level of education is a desired outcome of welfare itself, an analytical framework examining schooling as a welfare predictor and predictant can be highly favoured in guiding public policy, coupled with the need to delineate differential effects of education across other outcomes including its likelihood of becoming confounder in a system of multidimensional causal relationships. Grossman (2000) notes three possibilities of the correlation between formal schooling and health outcome that are deemed critical to advising public policy: a causality that runs from changes in levels of schooling to changes in health outcome; another that runs from changes in health status to changes in the stock of knowledge; and where there is no causality between the two outcomes of health and education status. The causality that runs from schooling to health is described as productive or allocative efficiency path. The productive efficiency suggests that the more highly educated a person is, the higher the likelihood of obtaining larger health output from given resources. That is, those with higher education are expected to be obliged with better employment 
opportunities and greater purchasing power over socio-economic products including health commodities. The allocative efficiency explains the importance of education in terms of better access to information about health alternatives, technologies and life enhancing behaviour (Kenkel 2000).

A reverse causality from health to schooling suggests higher proclivity for healthier children to go to school and stay in attendance throughout with more chances of excellence. Essentially, any current causality running from education to health outcome could have in fact emanated from past health status including that of the parents (Grossman 2000). Causality between schooling and health may not exist if observed correlation between the two outcomes is the result of other factors such as improved delivery of public services, cognitive and physical abilities, parental characteristics, and time preference (Griliches and Mason 1975; Grossman 2000).

Variants of the human capital model have investigated the differential effects of education across outcomes such as income earnings and health. Some suggest schooling tends to account for more variation in earnings than in health status but with 'smaller random component in income status than in health (Grossman and Kaestner 1997; Mincer 1974).

Education has knock-on-effect on many other sectors, and indeed could be the most critical determinant of poverty and economic growth. Literacy has been hypothesised and established as a critical measure of controlling population growth within the framework of the quantity-quality models (Black et al. 2005). Furthermore, farm household graduates with basic education are believed to be equipped with knowledge sufficient to significantly impact on agricultural productivity and rural transformation (Acker and Gasperini 2003). Some researchers have illuminated the relevance of schooling in discussing the large welfare differential effects expected from promoting the nonfarm sector for sustained poverty reduction relative to farming (Otsuka et al. 2009a). The farm sector is perceived as an indispensable initial source of financing education in the early stage of development for every society because at that time those interested in educating their children derive most of their incomes from farming. This precedence is however expected to diminish overtime as the accumulated capital from farming provides the opportunity to stimulate nonfarm jobs with chances of yielding higher returns to human capital than derived from farming. By this time the nonfarm sector would have been most vital in sustained reduction of rural poverty through transforming the agrarian economy as a critical measure of achieving national sustainable development.

At the macro level, the fluctuations of growth in many Sub-Saharan African countries could be explained by incapacity to generate a critical mass of talents and entrepreneurship, and policy ineffectiveness that derails the turning of masses of populations into more productive agents through literacy enhancement. Knowledge formation is an implicit prerequisite for any smooth riding up the ladder of economic growth and development [see stages of economic development in Rostow (1960)]; and also implicit in the effective translation of any financial capital into growth in the Harro-Domar models (Domar 1947; Harrod 1948). The argument for technology in the national production function is an explicit accentuation of the pivotal role of knowledge in economic transformation processes (Romer 1992; 1993; Solow 1956), as well as in structural change growth models (Chenery 1979; Lewis 1954). The structural transformative processes that are required to advance economies and the financial and technological capital needed as substratum and catalysts should be founded on a solid human capital platform for a state to effectively implement development strategies and achieve optimal and sustainable results.

It is somewhat peculiar that large segments of SSA remain swamped with illiteracy while the role of education for poverty reduction has long been emphasised. This paper has further illustrated this peculiarity, finding a strong correlation between poverty reduction and education in Sub-Saharan Africa.

Based on the World Bank Development Indicators, Figure 1 provides some impression of cross-country correlation between poverty and literacy in SSA. Panel (a) in the figure presents correlation for 31 countries including outlying nations of Swaziland, Zimbabwe and Equatorial Guinea; and panel (b) presents correlation for 28 countries dropping these outliers. The poverty variable is measured by headcount index, which is the ratio of those below the national poverty line compared to the total population, while literacy is measured by those 15 years and above that can read and write. These figures are averaged for the period 2000-12. Panel (a) shows very mild inverse relationship between poverty headcount index and literacy; the downward slope is suppressed by the outliers, in which high literacy is unexpectedly accompanied by high poverty. The downward slope becomes distinct as expected after dropping the outliers in panel (b), strongly suggesting that education has a substantial poverty reducing effect. Indeed, some growth performing countries such as Botswana, Namibia and Cape Verde have seen relatively high literacy levels accompanied by lower poverty headcount ratios in the sample. Low income countries such as Sierra Leone, Guinea, Guinea-Bissau, Central African Republic (CAR) and Chad with relatively low literacy rates are associated with higher poverty headcount ratios. This dichotomy suggests a need for increased investment in education for poverty reduction. 


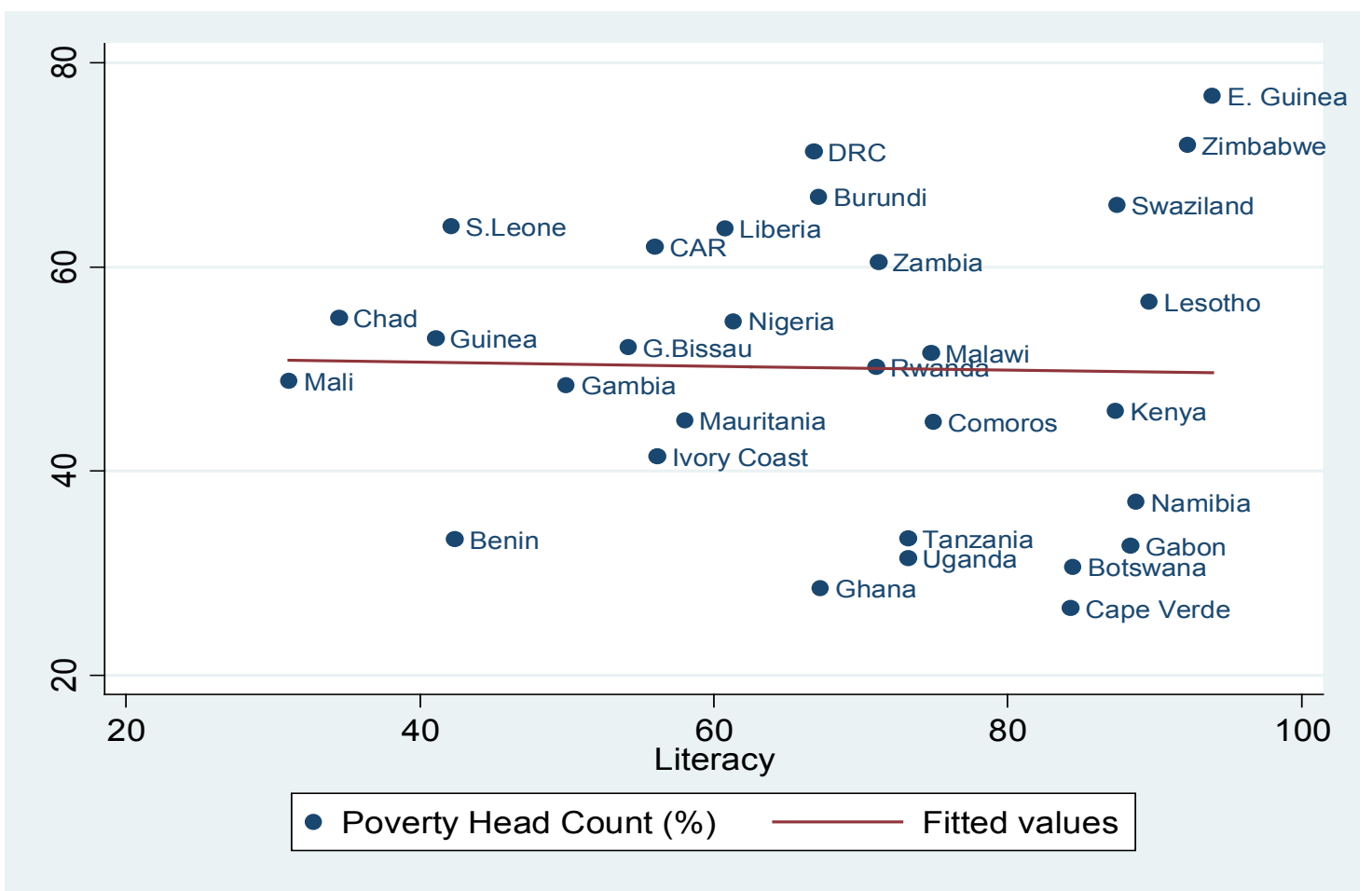

Panel (a). Thirty-one Countries

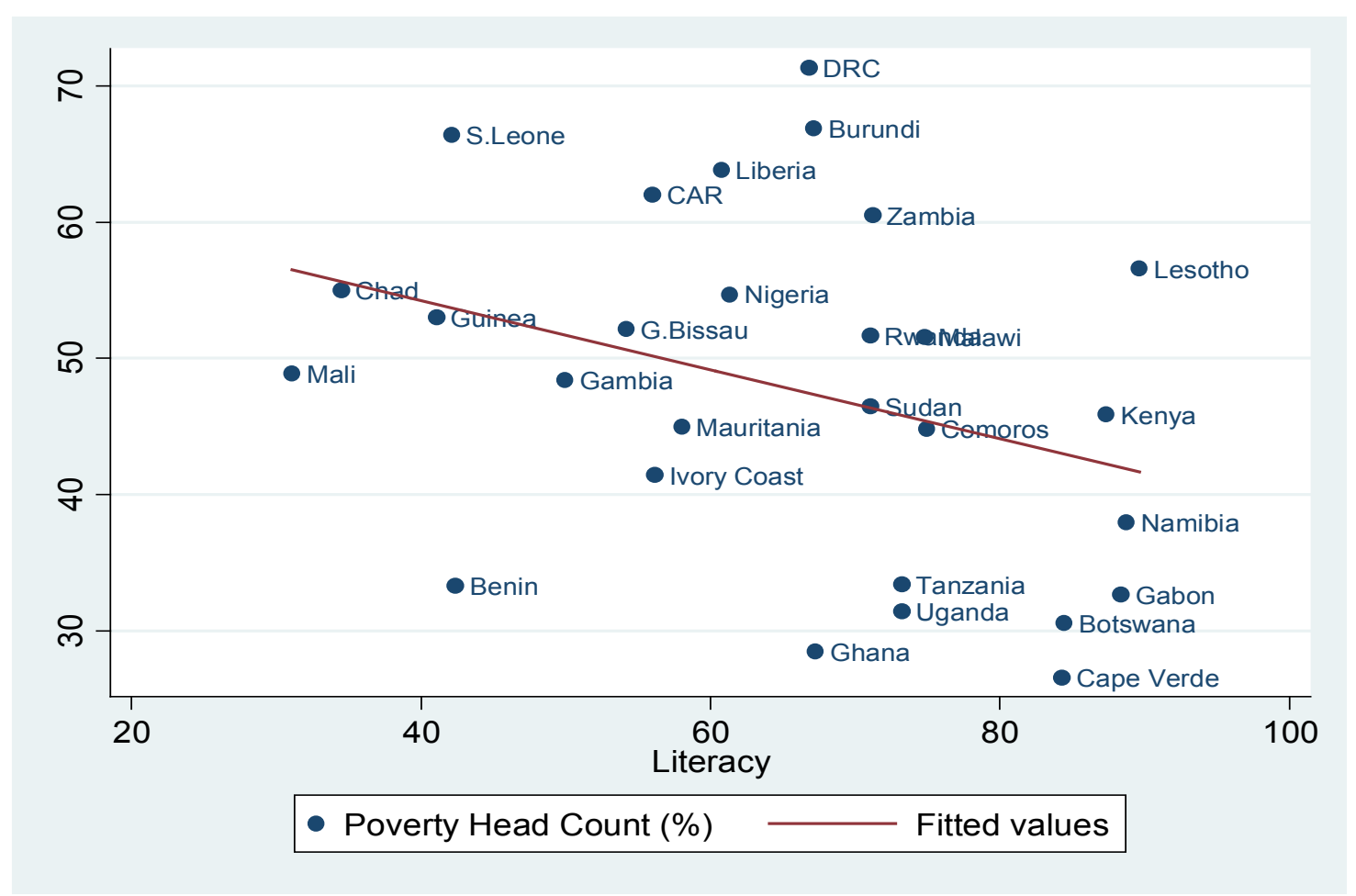

Panel (b). Twenty-eight Countries without Outliers

Sources: The World Bank Development Indicators.

Notes: As national literacy estimates which are mostly obtained from national census normally conducted every ten years and at different times for countries, the poverty headcount and literacy estimates are averaged for the period 2000-2012 for countries in the sample.

Figure 1. Literacy and Poverty in Sub-Saharan Africa 2000-2012 
The scenario presented by the outlying countries of Zimbabwe, Equatorial Guinea and Swaziland where high literacy is accompanied by high poverty headcount ratio suggests a need to prioritise governance reforms in those countries. This unexpected outlook is witnessed in Equatorial Guinea and Swaziland even though these nations are among the relatively high income countries on the continent. The literacy-poverty irony in the three countries could not be surprising, considering that these countries are globally notorious for their bad socio-economic and political governance. ${ }^{1}$ Meanwhile, there are rare cases in the sample, such as depicted for Benin (a low income country) where literacy is low but poverty headcount is substantially contained. Such cases have huge potential to rapidly grow and develop if massive investment in education is undertaken.

As can be seen from Figure 1, Benin and Sierra Leone virtually have the same literacy rate but very wide disparity in poverty headcount ratios; the latter's ratio is far higher than the former's. Although its literacy rate is relatively low, Benin is highly rated for good governance and human rights records. ${ }^{2}$ On the other hand, a long period of bad governance and political instability until 2002 has left Sierra Leone with enormous challenges over the years that require continued and substantial investments not only in education but in other critical development areas including institutional reforms to ensure meaningful reduction of poverty.

\subsection{Education and Poverty in Sierra Leone}

Sierra Leone is historically widely referenced as one of the African countries with brighter post-colonial genesis with relatively solid educational chances, although illiteracy was at a very low ebb at 7.7 percent at independence in 1961 (Hanlon 2005). The first tertiary education institution in West Africa, the Fourah Bay College, was founded in Sierra Leone in 1827 based on British Educational System, which played critical role in the training of the first corps of administrators, doctors and teachers in English-speaking West Africa in the first half of the $20^{\text {th }}$ century. Also, the country had the first schools for boys and girls based on Western Education founded in 1845 and 1849 respectively (Government of Sierra Leone, GoSL, 2010).
However, these opportunities have not been sustained and expanded to optimality for most of the post-independence period of the country, a period largely characterised by cascade of political instabilities and economic mismanagement and fluctuations. Literacy had only increased to 15 percent in 1970 , remaining at this level throughout the 1980s before the outbreak of the war (World Bank 1981; Banya 1993). The country's bad governance culminated into a bloody 10 year civil war during 1991-2001, befitting the resource-curse thesis of witnessing wide range of natural resources but being prone to conflict and governance traps that characterise the underdevelopment of many Sub-Sahara African Countries (Collier 2007; Moyo 2009; Sachs 2005).

Being highly reflective of the nexus between illiteracy, bad governance and poverty, the Sierra Leone's Constitution of 1991 declared free compulsory basic education at primary and junior secondary school levels. This was further backed during the country's post-conflict reconstruction phase that brought in extensive institutional re-engineering of the public sector. The Education Act of 2004 focusing on strengthening primary and junior secondary schooling with special emphasis on girls' education was passed. The Local Government Act 2004 was instituted to resuscitate Local Councils to facilitate service delivery at the community level. National poverty reduction programmes were developed, which had (and still have) education as central pillar. Yet, illiteracy has remained disquieting for the country as shown in Table 1, constructed from the Sierra Leone Integrated Household Surveys of 2003 and 2011. Those never in school increased proportionately from 50.41 percent in 2003/04 to 53.37 percent in 2011 overall. The school age sample population that were not in school increased from 30.21 to 37.96 percent. The disparity is wide between males and females, split at 42.56 and 57.56 percent in 2003/04, both increasing to 48.90 and 57.63 percent in 2011 . The disparity is wider between rural and urban settlements at a split of 61.05 and 31.62 percent in $2003 / 04$, both increasing to 65.56 and 30.55 percent in 2011.

\footnotetext{
${ }^{1}$ Zimbabwe's current president is serving more than three decades in office while it experiences frequent political and economic crisis and plunging of major development indicators; Equatorial Guinea has been equally inflicted with bad governance, reported of being immersed in high corruption and appalling human rights records in Africa (Puddington 2010); while the biggest challenge faced by Swaziland is controlling HIV epidemic, having the world's highest infection rate (Whiteside et al. 2006).

${ }^{2}$ In 2009, Benin scored highly on the Ibrahim Index of African Governance, ranked $15^{\text {th }}$ out of 53 African Countries with special reference to promoting safety, security, participation and human rights. It is also rated high on the Worldwide Press Freedom Index, ranked $53^{\text {rd }}$ out of 169 countries in 2009.
} 
Table 1. Household Members That Attended School and Those Who Did Not, 2003-2011

\begin{tabular}{cccccccc}
\hline Schooling & Total & 3-21 years & Male & Female & Rural & Urban \\
\hline SLIHS 2003 & & & & & & \\
\hline \multirow{2}{*}{$\begin{array}{c}\text { Attended } \\
\text { School }\end{array}$} & 9,935 & 7,306 & 5,488 & 4,447 & 4,982 & 4,953 \\
\cline { 2 - 7 } Never & $(49.59)$ & $(69.79)$ & $(57.44)$ & $(42.44)$ & $(38.95)$ & $(68.38)$ \\
\cline { 2 - 7 } & 10,098 & 3,163 & 4,067 & 6,031 & 7,808 & 2,290 \\
\hline Total & $(50.41)$ & $(30.21)$ & $(42.56)$ & $(57.56)$ & $(61.05)$ & $(31.62)$ \\
\hline SLIHS 2011 & 20,033 & 10,469 & 9,555 & 10,478 & 12,790 & 7,243 \\
\hline Attended & 17,590 & 8,005 & 9,423 & 8,167 & & 8,464 & \\
School & $(46.63)$ & $(62.04)$ & $(51.10)$ & $(42.37)$ & $(34.44)$ & $(69.45)$ \\
\hline \multirow{2}{*}{ Never } & 20,129 & 4,897 & 9,019 & 11,110 & 16,114 & 4,015 \\
\hline Total & $(53.37)$ & $(37.96)$ & $(48.90)$ & $(57.63)$ & $(65.56)$ & $(30.55)$ \\
\hline
\end{tabular}

Notes: Numbers represent observations in each category, and per cents ( percent) of the total households are in parentheses.

With respect to school age population, significant strides have been made in increasing enrolment at all levels especially at primary. Primary school enrolment increased from about 400,000 in late 1980 s to about 600,000 at the end of the war in 2001/02, from where it more than doubled reaching 1.3 million in $2006 / 07$, slightly slipping to 1.2 million in 2010. Secondary enrolment has also been increasing although far less than increases recorded at primary level (GoSL 2010).

The inelastic response of illiteracy (especially in rural areas) to increased public investment in education could stem from a number of factors, including ineffective service delivery chain and accountability in the educational sector, and public service in general (Collier 2007; Moyo 2009). Geographic accessibility of services by remote rural communities is another factor (Moulton 2001; Sachs 2005). Various locations especially in the rural areas suffer from geographic terrains characterized by widespread mountains and poor road conditions that would thwart state policies from providing services effectively.

This backdrop corroborates the continued documentation of Sierra Leone as an extremely poverty wracked nation. It has been repeatedly scored least or near the bottom in the UNDP's human development index of which literacy is a key measure. The country's poverty headcount recorded more than 80 percent at the outbreak of the war in 1991. It came down to 67 percent in 2003/04, and about 54 percent in 2011. Rural poverty has been most alarming at 79 percent in 2003/04, sliding down to not less than 67 percent in 2011 . Rural poverty size increased by about 63,000 persons during 2003-2011, reflecting the trend of SSA.

\section{Theoretical Background and Empirical Model}

\subsection{Theoretical Background}

Our empirical model follows various theoretical constructs of human capital investment models within the traditional microeconomic household optimization problem (Bardhan and Udry 1999; Becker 1981; Grossman 2000; Sahn and Stifel 2003). To demonstrate education-poverty nexus, this paper utilises human capital theoretical framework illustrating the importance of education, as well as health and income in fighting poverty and increasing human development. Both consumption expenditure (a measure of income) and human capital statuses (measured by levels of education and health in this paper) can be derived from a single household model. That is, among the problems a household seeks to solve involves not only consumption, but also education and health in a host of welfare optimization decisions. All of these affect the level of utility, $u$, the household derives at any point in time. The household's problem is therefore formally presented as follows:

$$
\max _{x, l, \theta, \beta} u(x, l, \theta, \beta, \emptyset ; A, Z, \rho)
$$

where $u($.$) is the utility function to maximize; x$ is the consumption of normal goods and services; $l$ is leisure; $\theta$ is education status demanded; $\beta$ is health status demanded; $\varnothing$ is other relevant household decisions; and $A, Z$ and $\rho$ are observable household, community and national characteristics that affect household utility respectively. Maximizing this utility function is subject to the following budget constraint:

$$
p x=w(T-l)+y
$$

where $p$ is a vector of prices, in this case over the purchase of normal goods and the acquisition of health and education; $w$ is a vector of household members' wages, $\mathrm{T}$ is a vector of the household members' maximum work hours; and $\mathrm{y}$ is household non-wage income. Underlying this utility maximizing problem is an educational production technology and biological (health) technology expressed in Eq. (3) and (4) below, technologies underlying other decisions are latent in the model (Sahn and Stifel 2003). The education production technology can be stated as:

$$
e_{i}=e\left(I_{e}, A, Z, \rho, \pi_{i}\right)
$$


and the health production technology is written as:

$$
h_{i}=h\left(I_{h}, A, Z, \rho, \mu_{i}\right)
$$

From Eq. (3), $e_{i}$ is educational status of household; $I_{e}$ is a vector of educational inputs which includes normal and health goods and services; and $\pi_{i}$ represents the unobservable individual family and community characteristics that affect the household. From Eq (4), $h_{i}$ is health status of the household which includes normal and education goods and services; and $I_{h}$ is a vector of health inputs; $\mu_{i}$ represents the unobservable individual family and community characteristics that affect the household health status. Solving the optimization problem defined by Eq. (1) to (4) derives the optimal education solution as follows:

$$
e_{i}=\hat{e}\left(x, h, A, Z, \rho, \epsilon_{i}\right)
$$

as well as the health optimal solution:

$$
h_{i}=\hat{h}\left(x, e, A, Z, \rho, \varepsilon_{i}\right)
$$

and optimal demand for normal goods and services:

$$
x_{i}=\hat{x}\left(h, e, A, Z, \rho, \tau_{i}\right)
$$

where $\epsilon_{i}, \varepsilon_{i}$, and $\tau_{i}$ are errors and the rest of the variables are as defined earlier. The presence of education, health and normal consumption variables $e_{i}, h_{i}$ and $x_{i}$ in each other's function from Eq. (5) to (7) above depicts the endogeneity problem underlying household welfare decisions.

Before presenting our final model for estimation, it is critical to reflect additionally on the optimisation solution from some of the human capital theoretical frameworks. Grossman's general equilibrium solution of human capital model produces two reduced form equations of stock of health, and vector of health related traded inputs/goods, both of which are functions of education, among other regressors and covariates (Grossman 2000). Becker and Mulligan (1997) specifies a non-recursive simultaneous equation operational model of four equations of health stock, permanent income, years of formal school, and time preference for the present, all of which directly or indirectly interact with each other in explaining household welfare decisions. Both specifications indicate the existence of simultaneity in human capital related models and have been empirically, systemically estimated to correct for endogeneity for efficient estimates.

The complexity of the welfare decision-making of households is also captured in Wagle's multidimensional poverty analytical framework involving the estimation of a non-recursive simultaneous equation system. Wagle employs a structural equation modelling (SEM) to analyse five latent, dependent factor variables that interact with each other to determine which among them are most crucial for policy. The five latent variables - derived with aid of factor analysis - are economic wellbeing; household capability; economic inclusion; political inclusion; and civic or cultural inclusion.

Most empirical studies reviewed for this paper including those on SSA have run single equation models in investigating determinants of education attainment. ${ }^{3}$ Factors found significant in determining education from these studies include: household income; household education; sex of child; size of land cultivated; application of modern farm technologies; household size; and time dummies. Other single equation studies have treated education as predictor or determinant of other development variables such as such mortality rates, health status, child nutrition, household income, occupational choices and migration (Lindelow 2003; Mackinnon 1995; amongst others).

\subsection{Empirical Model}

Against this background, our model has been based on a practical household decision making circumstance. It specifically draws on theories and empirical applications of human capital investment discussed in Becker and Mulligan (1997), Grossman (2000) and Wagle (2010).

We employ a two-level simultaneous equations approach to reveal the transmission mechanism through which education interrelates with other variables in explaining poverty. On the first level of our estimation, we utilise three-stage least squares (3SLS) methods with three equations system consisting of education (proxied by level of expenditure on child schooling in the household), level of spending on health and household income consumption. Two-stage least squares (2SLS) estimation could have been effective in handling endogeneity problem, but we use the 3SLS because it has an added advantage of accounting for envisaged problem of cross-equation error correlations that are common with household survey data. This is expected to render more efficient estimates in our simultaneous demand system.

On our second level estimation, we use a two-stage probit least squares (2SPLS) simultaneous system with two equations, consisting of a poverty headcount ratio equation in which the headcount ratio is a binary variable, and years of schooling of the household head as the second equation in which years of schooling is a continuous variable. This framework combines a probit (maximum likelihood) component determining the probabilities of households becoming poor or not poor, and an ordinary least square (OLS) component to estimate variable effects on years of schooling. This model enables us parametrically predict poverty probabilities/indices for the rural and urban areas and obtain estimates of the minimum investment required to eradicate poverty in the two sectors (Alvarez 1999; Keshk 2003).

We now turn to specifying our two empirical models. In matrix terms, our 3SLS system can be written as:

$$
Y_{i}^{\prime} \Gamma+X_{i}^{\prime} B=\varepsilon_{i}^{\prime} \text { for } i=1,2,3, \ldots \ldots \mathrm{N},
$$

where $Y^{\prime}=\left[Y_{C} Y_{E} Y_{H}\right]$ is a matrix of endogenous variables, in which $Y_{C}, Y_{E}$ and $Y_{H}$ denote total consumption income of household head, annual education expenditure of the household and health expenditure, respectively. 


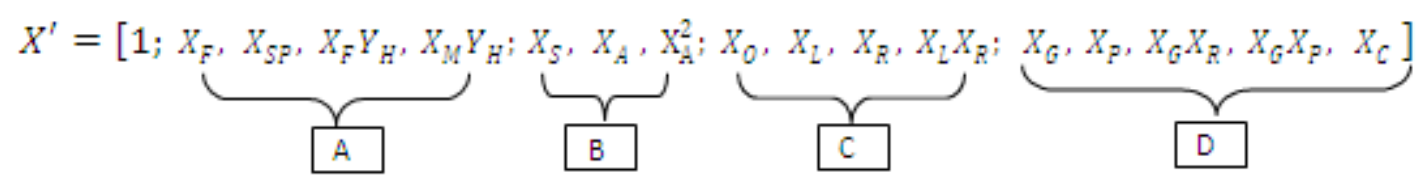

is a matrix of exogenous variables, where block A represents human capital variables, in which $X_{F}$ is years of schooling completed by household head, $X_{S P}$ years of schooling by spouse, $X_{F} Y_{H}$ is multiplicative variable for years of schooling of head and household spending on health, and $X_{S P} Y_{H}$ is multiplicative variable for years of schooling by spouses and spending on health; block B represents socio-economic status of household, in which $X_{S}$ is sex of the household head, $X_{A}$ is age of the head, and $X_{A}^{2}$ is square of age of household head; block C represents regional characteristics, in which $X_{O}$ is a factor variable denoting off-farm employment, $X_{L}$ is size of land owned, $X_{R}$ geographic location of household, $X_{L} X_{R}$ multiplicative variable for location of household and size of land owned; block D represents policy variables, in which $X_{G}$ is macroeconomic support in terms of central transfers (or allocations) to local councils, $X_{P}$ is public service delivery factor variable, $X_{G} X_{R}$ is multiplicative variable for macroeconomic support and location of household/local council, $X_{G} X_{P}$ is multiplicative variable for macroeconomic support and public service delivery, and $X_{C}$ is credit to the household.

In the above system, $\Gamma$ is a (3x3) matrix of unknown structural parameters of endogenous variables as follows:

$$
\Gamma=\left[\begin{array}{ccc}
1 & -\gamma_{E C} & -\gamma_{H C} \\
-\gamma_{C E} & 1 & 0 \\
-\gamma_{C H} & -\gamma_{E H} & 1
\end{array}\right]
$$

$B$ is a (17x3) matrix of unknown structural parameters of exogenous variables written as follows:

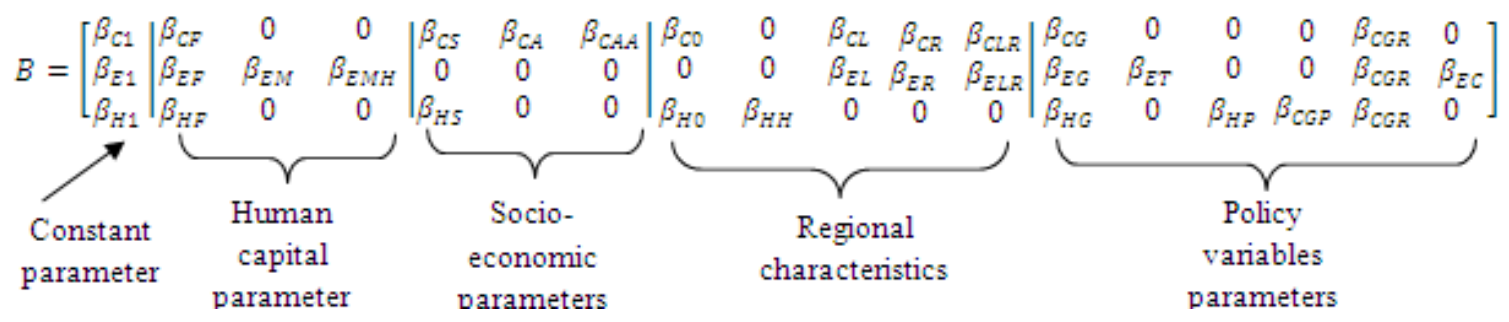

and $\varepsilon^{\prime}$ is an $(N \times 3)$ vector of structural errors written as $\varepsilon^{\prime}=\left[\varepsilon_{1}, \varepsilon_{2}, \varepsilon_{3}\right]$.

Now, our system of 2SPLS can be specified as:

$$
Z_{i}^{\prime} T+X_{i}^{\prime} P=v_{i}^{\prime}, \text { for } i=1,2,3, \ldots \ldots \mathrm{N}
$$

where $Z^{\prime}=\left[Z_{P} Z_{E}\right]$ is a matrix of endogenous variables, in which $Z_{P}$ is poverty headcount index, and $Z_{E}$ is years of schooling completed by household head;

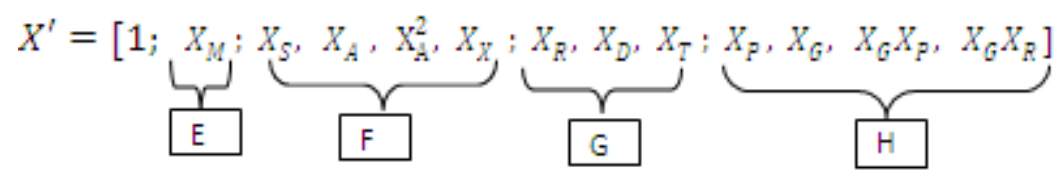

is a matrix of exogenous variables, where block E represents human capital variables as explained above; block $\mathrm{F}$ is socio-economic status variables as explained above; block $\mathrm{G}$ is regional characteristics, in which $X_{R}$ is as explained above, $X_{D}$ is right of trading land through the market, $X_{T}$ is time taken to access primary school; block $H$ is policy variables as explained above.

In the above system, $T$ represents a (2x2) matrix of unknown structural parameters of endogenous variables as follows:

$$
T=\left[\begin{array}{cc}
1 & -\gamma_{E P} \\
-\gamma_{P E} & 1
\end{array}\right]
$$

$P$ is a (17x3) matrix of unknown structural parameters of exogenous variables written as follows:

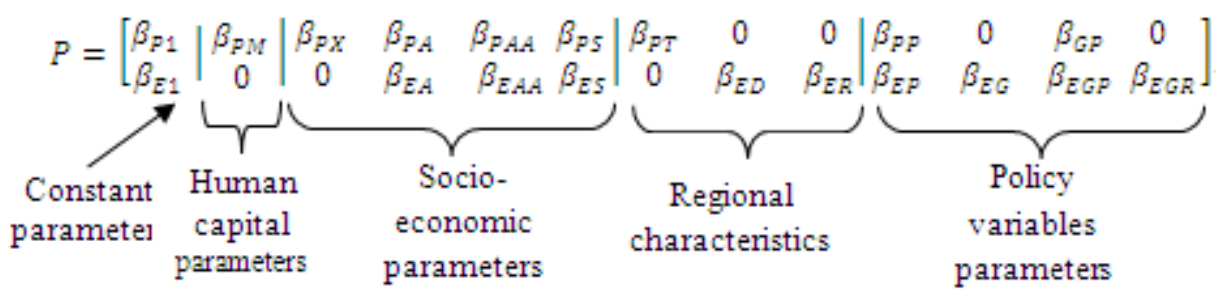

and $v^{\prime}$ is an $(N \mathrm{x} 2)$ vector of structural errors written as $v^{\prime}=\left[v_{1}, v_{2}\right]$. 


\section{Data and Empirical Results}

\subsection{Data and Variables}

The data for the analysis are obtained from the Sierra Leone Integrated Household Survey 2011. These surveys provide the most comprehensive sources of information for the analysis of poverty situation of the country. Our analysis is at the household level given the objective of the research. The survey gathered information from a total sample of 6,832 households nationwide split into 4,351 for the rural areas and 2,480 for the urban areas. After accounting for missing values, in addition to predicating the analysis on household heads with at least primary education, we have analysed 2,955 households from the rural areas, and 2, 268 from the urban areas in both the 3SLS and 2SPLS model.

For dependent variables in the 3SLS model, we employ log of household consumption $\left(Y_{C},\right)$, log of expenditure on child schooling $\left(Y_{E}\right)$ and $\log$ of expenditure on household health $\left(Y_{H}\right)$ to proxy levels of household income, education and health, respectively.

We use aggregate consumption expenditure as measure of living standard instead of income, following arguments in the literature regarding the need to look at income on the basis of aggregate consumption expenditure as a better measure of welfare (Deaton and Zaidi 2002; World Bank 2008). This particularly applies to African economies where majority of the population are engaged in small businesses, informal sector, working on their own land, and hardly keeping records of operations. This is why consumption approach has been utilised in many country cases and has been applied in informing the preparation of the poverty reduction strategies of Sierra Leone (World Bank 2008).

Researchers have modelled education in different forms depending on data availability, structure and context. As dependent variable, some have modelled it as the difference in years of schooling between survey periods or as the number of school years completed by children, while others have used the probability of school enrolment or the probability of completing various school grade levels. ${ }^{4}$ Given the context of our data we choose to model household expenditure on child schooling per year expressed in logarithm.

Regarding health status analysis, a number of researchers have analysed the probability of seeking certain types of healthcare in a binary framework of either seeking formal or informal care, or multinomial framework of seeking public, private or traditional/self-administered care (Kasirye et al. 2004; Lindelow 2003). Instead, we have modelled annual household expenditure on health as a continuous variable which has not been done in the literature reviewed.
In the 2SPLS model, we construct poverty headcount $\left(Z_{P}\right)$ as the dichotomous dependent variable taking value 1 if the head of the household is considered poor based on the national poverty line of Le1, 587,746 (US\$ 363), or 0 otherwise; and education level of household head as years of schooling of the household head $\left(Z_{E}\right)$ as the continuous dependent variable. By choosing the headcount ratio as one of the dependent variables we can predict changes in poverty derivable from changes in policy variables and estimate the minimum investment needed to eradicate poverty (Chaudhry 2003; Otsuka et al. 2009a; World Bank 2005).

For independent variables, this research notes from the literature that the observed variables characterizing household poverty are generally multitudinous, and are often categorized into individual level characteristics; household level characteristics; community level characteristics; regional characteristics; and macro/national level characteristics (Coromaldi and Zoli 2007; Mackinnon 1995; Mosley and Cohen 1984; Sahn and Stifel 2003; Sirven 2006; Ssewanyana et al. 2007; World Bank 2005). In this case, researchers have employed factor analysis to reduce large number of initially identified variables to a small and parsimonious set before running regressions (Wagle 2010; Coromaldi and Zoli 2007; Sahn and Stifel 2003; Sirven 2006; Ssewanyana et al. 2007). Given the objective of our research and the numerous but relevant variables that we have identified for the analysis, we have included both observed and factor variables. The factor variables are derived by using the principal component extraction method.

Table 2 presents definition and summary statistics of the variables included in the analysis. Among the regressors, the years of schooling of the household head $\left(X_{F}\right)$ is exogenous only in the first model. The variable $X_{S P}$ (in the 2SPLS model and entered only in the second equation) is years of schooling of the spouse which is expected to encourage the head to attain higher education and expected to reduce poverty count through improved household development information and balance in decision making over the allocation of resources.

The two variables represent proxies of parental education and are expected to have positive effect on household income, child education and health. The higher their values are, the higher the household chances of accessing off-farm jobs with higher returns with which they are expected to increase spending on goods and services including child education and health inputs; this is consequently expected to reduce the probability of becoming poor (Grossman 2000). 
Table 2. Descriptive Statistics of the Variables

\begin{tabular}{|c|c|c|c|c|c|c|c|c|c|}
\hline \multirow{2}{*}{ Variable } & \multirow{2}{*}{ Description } & \multicolumn{4}{|c|}{ Rural } & \multicolumn{4}{|c|}{ Urban } \\
\hline & & Mean & $\mathrm{SD}$ & Min & Max & Mean & $\mathrm{SD}$ & Min & Max \\
\hline $\begin{array}{c}\text { Log Income Consumption } \\
\left(\mathrm{Y}_{\mathrm{C}}\right)\end{array}$ & $\begin{array}{l}\text { Continuous } \\
\text { variable }\end{array}$ & 14.15 & 0.80 & 12.11 & 22.47 & 14.78 & 0.97 & 11.55 & 22.84 \\
\hline $\begin{array}{l}\text { Log Investment in Child } \\
\text { Education }\left(\mathrm{Y}_{\mathrm{E}}\right)\end{array}$ & $\begin{array}{l}\text { Continuous } \\
\text { variable }\end{array}$ & 10.98 & 1.88 & 6.91 & 16.62 & 11.70 & 2.55 & 6.91 & 17.07 \\
\hline $\begin{array}{l}\text { Log Investment in Health } \\
\qquad\left(\mathrm{Y}_{\mathrm{H}}\right)\end{array}$ & $\begin{array}{l}\text { Continuous } \\
\text { variable }\end{array}$ & 8.93 & 1.29 & 6.91 & 18.08 & 9.28 & 1.64 & 6.91 & 19.20 \\
\hline $\begin{array}{c}\text { Years schooling } \\
\text { completed by household } \\
\text { head }\left(\mathrm{X}_{\mathrm{F}}\right)\end{array}$ & $\begin{array}{l}\text { Continuous } \\
\text { variable }\end{array}$ & 10.02 & 5.00 & 3.00 & 22.00 & 15.85 & 5.01 & 3.00 & 22.00 \\
\hline $\begin{array}{c}\text { Years completed by } \\
\text { mothers }\left(X_{M}\right)\end{array}$ & $\begin{array}{l}\text { Continuous } \\
\text { variable }\end{array}$ & 3.59 & 2.23 & 3.00 & 20.00 & 7.24 & 5.94 & 3.00 & 20.00 \\
\hline $\begin{array}{c}\text { Mothers education times } \\
\text { household income } \\
\left(\mathrm{X}_{\mathrm{M}} * \mathrm{Y}_{\mathrm{C}}\right)\end{array}$ & $\begin{array}{l}\text { Continuous } \\
\text { variable }\end{array}$ & 50.82 & 32.40 & 36.41 & 300.14 & 107.40 & 89.79 & 34.66 & 343.30 \\
\hline $\begin{array}{c}\text { Health expenditure times } \\
\text { years of } \\
\text { Education }\left(\mathrm{Y}_{\mathrm{H}} * \mathrm{X}_{\mathrm{F}}\right)\end{array}$ & $\begin{array}{l}\text { Continuous } \\
\text { variable }\end{array}$ & 112.14 & 64.13 & 20.72 & 332.38 & 187.98 & 77.47 & 20.72 & 363.52 \\
\hline Household size $\left(\mathrm{X}_{\mathrm{S}}\right)$ & $\begin{array}{l}\text { Continuous } \\
\text { variable }\end{array}$ & 6.33 & 2.64 & 1.00 & 24.00 & 5.76 & 3.30 & 1.00 & 30.00 \\
\hline $\begin{array}{l}\text { Off-farm employment } \\
\text { opportunity }\left(\mathrm{X}_{\mathrm{O}}\right)\end{array}$ & $\begin{array}{c}\text { Factor } \\
\text { Variable }\end{array}$ & -0.47 & 0.80 & -0.88 & 1.99 & 0.62 & 0.90 & -0.88 & 1.99 \\
\hline $\begin{array}{l}\text { Geographic Location of } \\
\text { the household }\left(X_{R}\right)\end{array}$ & $\begin{array}{c}\text { Factor } \\
\text { Variable }\end{array}$ & -0.29 & 0.84 & -2.55 & 2.05 & 0.58 & 1.02 & -2.55 & 2.05 \\
\hline $\begin{array}{l}\text { Macroeconomic support } \\
\text { (central transfers) }\left(\mathrm{X}_{\mathrm{G}}\right)\end{array}$ & $\begin{array}{c}\text { Factor } \\
\text { Variable }\end{array}$ & 0.14 & 1.00 & -3.57 & 3.36 & -0.27 & 0.98 & -4.22 & 2.79 \\
\hline $\begin{array}{l}\text { Macroeconoic support } \\
\text { times Location }\left(\mathrm{X}_{\mathrm{G}} * \mathrm{X}_{\mathrm{R}}\right)\end{array}$ & $\begin{array}{c}\text { Factor } \\
\text { Variable }\end{array}$ & -0.31 & 0.90 & -6.34 & 6.04 & -0.54 & 1.07 & -8.49 & 3.00 \\
\hline $\begin{array}{c}\text { The size of land owned by } \\
\text { head }\left(\mathrm{X}_{\mathrm{L}}\right)\end{array}$ & $\begin{array}{c}\text { Continuous } \\
\text { variable }\end{array}$ & 10.27 & 26.25 & 0.00 & 625.16 & 9.65 & 44.30 & 0.00 & 820.37 \\
\hline $\begin{array}{c}\text { Land size times location } \\
\left(\mathrm{X}_{\mathrm{L}} * \mathrm{X}_{\mathrm{R}}\right)\end{array}$ & $\begin{array}{c}\text { Factor } \\
\text { Variable }\end{array}$ & -4.15 & 33.16 & -1098.97 & 523.69 & -0.62 & 26.58 & -365.54 & 237.23 \\
\hline $\begin{array}{l}\text { age of household head } \\
\left(\mathrm{X}_{\mathrm{A}}\right)\end{array}$ & $\begin{array}{l}\text { Continuous } \\
\text { variable }\end{array}$ & 46.01 & 14.81 & 0.00 & 98.00 & 43.48 & 13.94 & 16.00 & 95.00 \\
\hline $\begin{array}{l}\text { square of age of household } \\
\text { head }\left(\mathrm{X}_{\mathrm{AA}}\right)\end{array}$ & $\begin{array}{c}\text { Continuous } \\
\text { variable }\end{array}$ & 2336.09 & 1495.46 & 0.00 & 9604.00 & 2084.65 & 1326.32 & 256.00 & 9025.00 \\
\hline $\begin{array}{l}\text { Log of credit to } \\
\text { households }\left(X_{C}\right)\end{array}$ & $\begin{array}{l}\text { Continuous } \\
\text { variable }\end{array}$ & 8.43 & 2.41 & 6.91 & 16.60 & & 2.33 & 6.91 & 17.37 \\
\hline Housing $\left(\mathrm{X}_{\mathrm{H}}\right)$ & $\begin{array}{c}\text { Factor } \\
\text { Variable }\end{array}$ & -0.60 & 0.62 & -2.16 & 2.13 & 2268.00 & 0.79 & 0.85 & -2.27 \\
\hline $\begin{array}{l}\text { Public service delivery } \\
\text { effectiveness by local } \\
\text { councils }\left(\mathrm{X}_{\mathrm{P}}\right)\end{array}$ & $\begin{array}{l}\text { Factor } \\
\text { Variable }\end{array}$ & 0.07 & 1.10 & -1.97 & 2.42 & -0.14 & 0.80 & -1.96 & 2.29 \\
\hline $\begin{array}{l}\text { Macroeconomic support } \\
\text { times council effectiveness } \\
\left(\mathrm{X}_{\mathrm{G}} * \mathrm{X}_{\mathrm{P}}\right)\end{array}$ & $\begin{array}{l}\text { Factor } \\
\text { Variable }\end{array}$ & -0.09 & 1.13 & -5.54 & 6.22 & 0.15 & 0.90 & -5.27 & 3.76 \\
\hline
\end{tabular}

Notes: All the variables have the same number of observations of 2955 and 2268 for rural and urban area, respectively. Borrowed from Bangura (2015, pp.344-347), off-farm employment factor variable $\left(\mathrm{X}_{0}\right)$ is obtained using the measures: whether household head's main income derived from off-farm employment or not, whether household head work for wage or not, and whether household head is engaged in business activity or not; geographic local of household facto variable $\left(\mathrm{X}_{R}\right)$ is obtained using the measures: whether household resided in the west, south, east or north, whether located in coastal district, and religion of the household head; macroeconomic support (including central transfers to local councils) factor variable $\left(\mathrm{X}_{\mathrm{G}}\right)$ :central transfers to local councils towards agricultural programmes, central transfers to councils towards education programmes, central transfers to councils towards health programmes, amount of credit received by households, regional food price index factor, and regional non-food price index factor; the housing factor variable $\left(\mathrm{X}_{\mathrm{H}}\right)$ is obtained using the measures: number of rooms in the household, whether one household shares room(s) with another, construction material for outside wall, material used for floor, material used for roofing, source of cooking energy, source of energy for lighting, refuge disposal methods, source of drinking water, and toilet facility type; and public service delivery effectiveness by local council $\left(\mathrm{X}_{\mathrm{p}}\right)$ is obtained using the measures: local councils governance performance score, frequency of visits to communities by local councillors, local public knowledge of councillors, public perception of responsiveness to community needs by councils, public satisfaction with local council budget spending, public level of trust in the operations of the local councils, household participation score in social \& political associations, and receipt of assistance due to participation in hard times. 
Expenditure on health variable $\left(Y_{\mathrm{H}}\right)$ is expected to have positive impact on household consumption and child education and negative impact on poverty headcount ratio, as improved health status increases not only the activity of households at workplace but children's participation in school with overall likelihood to increase both current and future incomes. ${ }^{5}$ We have however further hypothesised that the marginal effect of health expenditure on welfare is conditional on years of schooling of the head denoted by $Y_{H} * X_{F}$. This is important in that the more educated an individual is the more exposed $\mathrm{s} / \mathrm{he}$ is to information on the value of health for welfare, and the more they will spend on healthcare, thereby increasing the chance of participation in the labour market, earning more income, spending more on child schooling and reducing overall poverty. ${ }^{6}$

The off-farm employment variable $\left(X_{O}\right)$ is a factor/index regressor extracted through factor analysis based on two significant measures: whether households were engaged in off-farm sector as main source of income or not; and whether generally engaged in wage employment besides farming as the case may. This factor is expected to positively impact on household income, child education, and health in terms of an expected positive differential effect on welfare from engaging in wage employment and other income generating activities relative to farming (Otsuka et al. 2009a).

The variable $X_{X}$ is the gender of the household head. Male headed households are expected to have higher chances of reducing poverty not only because it increases chances of years of schooling of head but because males generally take more dominant position especially in the rural areas in terms of access to resources.

Regarding the socio-economic status variables, $X_{A}$ is the age of the household head, and $X_{A}^{2}$ is the square of the age of the household head. As individuals ascend to maturity and enter the economically active age range, they are expected to earn more, reduce poverty, and increase household chances of acquiring higher education (expectation based on $X_{A}$ ); but overtime, as they become economically inactive with age, their income could be expected to dwindle with chances of increasing poverty in the absence of inadequate savings for retirement or old age (expectation based on $X_{A}^{2}$ ). The variable $X_{S}$ is household size, a measure of burden on household resources expected to increase poverty and decrease chances of education attainment.

As regional variables, $X_{T}$ is time taken to access primary school, with the expectation that the shorter it is the more likely that the head would be able to earn more years in school and increase chance of reducing poverty. The variable $X_{L}$ is size of land owned by household head. This is expected to be a vital asset to the household, and the more of it is possessed the more the chances of increasing welfare, through increased farm acreage and output or through trading of land in the market for investment in vital sectors

5Grossman (2000) argues this is the productive efficiency resulting from financial benefit from improved health.

6 This is consistent with the allocative efficiency argument due to the informational benefit from improved health (Grossman 2000; MacKinnon 1995). such as child education. We have however further hypothesised that the marginal effect of land size on welfare is conditioned on the geographic location of the household as measured by the variable, $X_{L} * X_{R}$. The geographic location of the household is a primary factor variable, $X_{R}$, measured by whether household is located in the west, south, east or northern region; ${ }^{7}$ whether the head is a Muslim by denomination or Christian; and whether located in a district with a local council administration scored high in service delivery performance. The higher the factor scores on this variable, the more its positive welfare effect is expected with regard to residing in a region with better socio-economic services.

For policy variables, $X_{G}$ is macroeconomic support provided to local councils as a factor variable measured by central transfers towards district agriculture programmes, health programmes, and education programmes. ${ }^{8}$ The more the transfers to councils in these sectors, the more the macro factor scores with respect to household located in a particular district, and the more it is expected that this will have positive welfare effects. We further hypothesise, however, that the marginal effect of the macro factor on welfare is conditioned on the location of the local councils denoted by the variable $X_{G} * X_{R}$, and the effectiveness of service delivery by the councils denoted by $X_{G} * X_{\mathrm{P}}$. The variable public service delivery $\left(X_{P}\right)$ is a primary factor regressor with expected positive welfare effect and measured by a combination of observed sub-variables: local public satisfaction with budget spending; public perception of the responsiveness of councils to community needs; public knowledge of councillors; public trust in the operations of the councils; and rate of visiting communities by local councillors. ${ }^{9}$

Other variables include $X_{D}$, a dummy quantity indicating whether the household head has right to trade land allocated through the market or not, and it is expected to have positive effect on welfare; the variable $X_{T}$ is time taken to access primary school from the household to control for the effect of provision of community infrastructure on welfare, which is expected to have positive relationship with poverty headcount ratio. The variable $X_{H}$ is housing factor controlling for effect of preventive healthcare on welfare measured by indicators including types of toilet facilities, refuse disposal method and condition of dwelling structures. This is expected to have positive welfare effect through improved health status of the household. And $X c$ is credit support to the household expected to positively impact on welfare.

7The Western Area has the capital city of Freetown, while the southern region is home to the second capital city.

8 Central transfers data are obtained from published national budgets of Sierra Leone.

9Data on public perception of the effectiveness of councils is obtained from the Comprehensive Local Government Performance Assessment periodically conducted by the government with assistance from the World Bank. 


\subsection{Nexus between Education and Poverty: Three-stage Least Squares Model}

Table 3. Three-Stage Least Squares Empirical Results

\begin{tabular}{|c|c|c|c|c|c|c|}
\hline & \multicolumn{2}{|c|}{$\begin{array}{c}\text { Log Income Consumption } \\
\left(Y_{C}\right)\end{array}$} & \multicolumn{2}{|c|}{$\begin{array}{l}\text { Log Investment in Child } \\
\text { Education }\left(Y_{E}\right)\end{array}$} & \multicolumn{2}{|c|}{$\begin{array}{l}\text { Log Investment in } \\
\text { Health }\left(Y_{H}\right)\end{array}$} \\
\hline & Rural & Urban & Rural & Urban & Rural & Urban \\
\hline $\begin{array}{l}\text { Years schooling completed by } \\
\text { household head }\left(X_{F}\right)\end{array}$ & $\begin{array}{c}-0.076 * * \\
(0.016)\end{array}$ & $\begin{array}{l}-0.012 \\
(0.029)\end{array}$ & $\begin{array}{l}0.096^{*} \\
(0.015)\end{array}$ & $\begin{array}{c}1.821 \\
(0.049)\end{array}$ & $\begin{array}{l}0.017 * \\
(0.006)\end{array}$ & $\begin{array}{c}0.014 \\
(0.016)\end{array}$ \\
\hline $\begin{array}{c}\text { Log Health expenditure by the } \\
\text { Household }\left(Y_{H}\right)\end{array}$ & $\begin{array}{l}2.269 * * * \\
(0.167)\end{array}$ & $\begin{array}{l}1.398^{*} \\
(0.150)\end{array}$ & $\begin{array}{l}0.752 * * * \\
(0.399)\end{array}$ & $\begin{array}{r}4.389 * * \\
(0.607)\end{array}$ & - & - \\
\hline Log household spending $\left(Y_{C}\right)$ & - & $\begin{array}{l}- \\
-\end{array}$ & $\begin{array}{l}8.899 * * \\
(1.927)\end{array}$ & $\begin{array}{l}3.650 * \\
(1.821)\end{array}$ & $\begin{array}{c}0.437 * * * \\
(0.015)\end{array}$ & $\begin{array}{l}0.713 * \\
(0.064)\end{array}$ \\
\hline Years completed by mothers $\left(X_{M}\right)$ & - & - & $\begin{array}{c}35.455^{*} \\
(7.516)\end{array}$ & $\begin{array}{c}14.751^{*} \\
(4.135)\end{array}$ & - & - \\
\hline Mothers education times household income $\left(X_{M} * Y_{C}\right)$ & $\begin{array}{l}- \\
-\end{array}$ & $\begin{array}{l}- \\
-\end{array}$ & $\begin{array}{c}-2.471 * * \\
(0.522)\end{array}$ & $\begin{array}{l}-1.009^{*} \\
(0.283)\end{array}$ & $\begin{array}{l}- \\
-\end{array}$ & $\begin{array}{l}- \\
-\end{array}$ \\
\hline $\begin{array}{l}\text { Health expenditure time years of } \\
\text { Education }\left(Y_{H^{*}} X_{F}\right)\end{array}$ & $\begin{array}{c}0.003 * * * \\
(0.001)\end{array}$ & $\begin{array}{l}-0.001 \\
(0.002)\end{array}$ & $\begin{array}{l}- \\
-\end{array}$ & $\begin{array}{l}- \\
-\end{array}$ & $\begin{array}{l}- \\
-\end{array}$ & $\begin{array}{l}- \\
-\end{array}$ \\
\hline Household size $\left(X_{S}\right)$ & $\begin{array}{c}-0.045^{* *} \\
(0.025)\end{array}$ & $\begin{array}{l}-0.051 \\
(0.030)\end{array}$ & - & $\begin{array}{l}- \\
-\end{array}$ & $\begin{array}{l}0.022 * \\
(0.011)\end{array}$ & $\begin{array}{r}0.038^{* *} \\
(0.021)\end{array}$ \\
\hline Housing $\left(X_{H}\right)$ & - & - & - & - & $\begin{array}{c}0.003 \\
(0.012)\end{array}$ & $\begin{array}{l}-0.007 \\
(0.039)\end{array}$ \\
\hline Off-farm employment opportunity $\left(X_{O}\right)$ & $\begin{array}{l}0.173^{*} \\
(0.106)\end{array}$ & $\begin{array}{c}0.092 \\
(0.099)\end{array}$ & - & - & $\begin{array}{c}-0.073 * \\
0.114\end{array}$ & $\begin{array}{l}-0.065 \\
(0.070)\end{array}$ \\
\hline $\begin{array}{l}\text { Geographic Location of } \\
\text { the household }\left(X_{R}\right)\end{array}$ & $\begin{array}{c}0.003 \\
(0.021)\end{array}$ & $\begin{array}{c}0.001 \\
(0.044)\end{array}$ & - & - & - & - \\
\hline $\begin{array}{l}\text { Macroeconomic support } \\
\text { (central transfers) }\left(X_{G}\right)\end{array}$ & $\begin{array}{l}0.240^{*} \\
(0.068)\end{array}$ & $\begin{array}{l}-0.138 \\
(0.122)\end{array}$ & $\begin{array}{l}-0.030 * \\
(0.087)\end{array}$ & $\begin{array}{c}-0.441 * * \\
(0.264)\end{array}$ & $\begin{array}{c}-0.106^{*} \\
(0.030)\end{array}$ & $\begin{array}{c}0.098 \\
(0.087)\end{array}$ \\
\hline Macroeconoic support times & $0.110^{* *}$ & $0.300^{* *}$ & $-0.210^{*}$ & $0.654 * *$ & $0.009 * *$ & $-0.218^{\prime}$ \\
\hline Location $\left(X_{G} * X_{R}\right)$ & $(0.073)$ & 0.131 & $(0.076)$ & $(0.309)$ & $(0.033)$ & $(0.092)$ \\
\hline Public service delivery effectiveness by local councils $\left(X_{P}\right)$ & - & $\begin{array}{l}- \\
-\end{array}$ & - & - & $\begin{array}{c}0.003 \\
(0.008)\end{array}$ & $\begin{array}{l}-0.001 \\
(0.024)\end{array}$ \\
\hline $\begin{array}{l}\text { Macroeconomic support times council effectiveness } \\
\qquad\left(X_{G} * X_{P}\right)\end{array}$ & - & $\begin{array}{l}- \\
-\end{array}$ & $\begin{array}{l}- \\
-\end{array}$ & - & $\begin{array}{l}0.001 * * \\
(0.009)\end{array}$ & $\begin{array}{c}0.004 \\
(0.029)\end{array}$ \\
\hline The size of land owned by head $\left(X_{L}\right)$ & $\begin{array}{l}-0.001 \\
(0.001)\end{array}$ & $\begin{array}{l}0.000 * \\
(0.002)\end{array}$ & $\begin{array}{l}0.000 * \\
(0.004)\end{array}$ & $\begin{array}{l}0.008 \\
(0.008)\end{array}$ & - & - \\
\hline Land size times location $\left(X_{L} * X_{R}\right)$ & 0.000 & $\begin{array}{c}0.001 \\
(0.003)\end{array}$ & $\begin{array}{c}0.000 \\
(0.003)\end{array}$ & $\begin{array}{c}0.002 \\
(0.017)\end{array}$ & $\begin{array}{l}- \\
-\end{array}$ & - \\
\hline age of household head $\left(X_{A}\right)$ & $\begin{array}{c}0.001 \\
(0.065)\end{array}$ & $\begin{array}{l}0.001 * \\
(0.009)\end{array}$ & - & - & $\begin{array}{l}- \\
-\end{array}$ & $\begin{array}{l}- \\
-\end{array}$ \\
\hline square of age of household head $\left(X_{A A}\right)$ & $\begin{array}{c}0.000 \\
(0.012)\end{array}$ & $\begin{array}{c}0.000 \\
(0.000)\end{array}$ & $\begin{array}{l}- \\
-\end{array}$ & $\begin{array}{l}- \\
-\end{array}$ & $\begin{array}{l}- \\
-\end{array}$ & $\begin{array}{l}- \\
-\end{array}$ \\
\hline $\log$ of credit to households $\left(X_{C}\right)$ & - & - & $\begin{array}{c}0.005 \\
(0.030)\end{array}$ & $\begin{array}{l}-0.080 \\
(0.088)\end{array}$ & $\begin{array}{l}- \\
-\end{array}$ & $\begin{array}{l}- \\
-\end{array}$ \\
\hline Constant & $\begin{array}{c}-5.332 * * * \\
(1.513)\end{array}$ & $\begin{array}{l}2.118 \\
(1.456)\end{array}$ & $\begin{array}{c}-123.99 * \\
(27.588)\end{array}$ & $\begin{array}{l}-80.90^{*} \\
(25.208)\end{array}$ & $\begin{array}{c}2.396^{* * * *} \\
(0.238)\end{array}$ & $\begin{array}{l}-1.521^{*} \\
(0.968)\end{array}$ \\
\hline $\mathrm{N}$ & 2955 & 2268 & 2955 & 2,268 & 2955 & 2,268 \\
\hline Chi-Square & $\begin{array}{c}1793 \\
(0.00)\end{array}$ & $\begin{array}{c}244.16 \\
(0.00)\end{array}$ & $\begin{array}{l}96.35 \\
(0.00)\end{array}$ & $\begin{array}{l}135.31 \\
(0.00)\end{array}$ & $\begin{array}{c}1054 \\
(0.00)\end{array}$ & $\begin{array}{c}219.19 \\
(0.00)\end{array}$ \\
\hline
\end{tabular}

Notes: $* * *$ denotes significant estimates at 1 percent; $* *$ significance at 5 percent; and *denotes significance at 10 percent; standard errors are in parentheses. 
Table 3 shows the coefficient estimates obtained for both rural and urban areas based on the three-stage least squares model. Years of schooling completed by the household head is found to be directly significant in affecting rural income consumption but unexpectedly has negative sign. However, tracing its effect through health spending suggests years of schooling has a positive and significant indirect impact on income. But, notwithstanding, at a coefficient of 0.039 , its positive indirect effect is outstripped by the negative direct effect of -0.076 , leaving a net negative effect of $-0.037 . .^{10}$ But the evidence that years of schooling has positive indirect effect through health investment may suggests its direct negative impact on income could only prevail in the short run when trade-offs and income substitution effects are unavoidable among the competing investment needs of a low income household. This suggests, under the current circumstances surrounding rural households, increased spending on education with the current low level of income of households may not see them grow out of poverty in the short run significantly since there are other necessities to meet. None of these effects are significant in urban areas.

Years of schooling of the head does directly and positively affect current spending on child education, and it is reinforced by a positive and significant indirect effect through health investment, leaving a net effect on child education of 0.109 above the direct effect of 0.096. Both effects are insignificant in the urban areas.

Health spending has direct and significant effect on both rural and urban income consumption, and larger in the rural than urban areas, comparing the two coefficients of 2.269 and 1.398. Its effect on child education is directly significant in both areas, with the urban coefficient, here, far outweighing the rural coefficient comparing 4.389 to 0.752 .

There is direct and positive impact of household income on child education in both areas as expected, with coefficient of the rural areas exceeding the urban coefficient, comparing 8.899 to 3.650. The income effect on health in the two areas is positive with not wide differential.

Spouse's years of schooling has positive and direct impact on child schooling for both the rural areas and urban areas, with the impact in the rural areas more than doubles the impact of the urban areas comparing 35.45 and 14.75 estimates. At the margin, however, the data suggests that the direct impact of spouse education on child schooling may drop as household income increased, and more so in the rural areas than in the urban areas.

The marginal impact of health spending on income relative to the head's level of education is positive for the rural areas, with positive indirect effect on child education. Its effect does not come out significant for the urban areas.

Household size has the expected direct negative effect on household income, with narrow differential between the rural and urban areas, but only significant in the rural case. The evidence suggests some diseconomies of large size in the rural areas such as spreading resources thinly across numerous members in households, especially where incomes are low. This is accompanied by negative indirect effect on rural child education estimated at -0.400 and rural health investment at -0.020 . The negative size-induced indirect income effect on rural health nearly offsets the positive short run (direct) impact of household size on rural health estimated at 0.022 . There is no indirect size-induced income effect on urban education and health spending since the direct effect of household size on income is insignificant. However, there is direct and significant positive impact of household size on health spending in urban areas estimated at 0.038 . This suggests that there are some economies of large size in urban households.

The housing factor does not come out significant in affecting health in both sectors. Off-farm employment factor directly positively affect household income for the rural areas only, with an indirect income induced effect on child education and health at rates of 1.540 and 0.076 respectively; although it suggests that in the short run there would be a direct negative effect on health spending. The geographic location factor does not come out significant for both rural and urban sectors in the income equation it was entered-perhaps under the current prevailing high costs of living, the expenditure budgets of households may have been equally seriously affected in all locations.

The macroeconomic factor (transfers to local councils) directly and positively affects household income consumption for the rural sector, with indirect effect on child education and health at rates 2.136 and 0.105 units. But there is a counter macroeconomic direct effect on rural child education and health (negative impact), inducing an indirect effect (through health) that more than offsets the direct effect on income earlier.

The evidence indicates that the expected impact of macroeconomic policies on community poverty depends largely on the location of the local councils the transfers are going; all marginal coefficients of macroeconomic support conditional on council location are directly significant with mixed sign across the equations. This suggests the need for significant improvement in service delivery and projects implemented with central resources in certain localities relative to the others.

The size of land owned is not significant in the rural regression; and magnitude of impact negligible for the urban sector where it shows significance. Age of household head is not significant too, as well as credit given to household.

We now turn to look at the extent to which education and other factors can predict reductions in poverty headcount using the 2SPLS as key aspect in addressing the research objective.

\footnotetext{
${ }^{10}$ The direct effect of the "years of schooling" on "health spending" is 0.017 , and that of "health spending" on "rural income consumption" is 2.269 for rural area. Therefore, the indirect effect of years of schooling on income is: $0.017 * 2.269=0.039$ for the rural area.
} 


\subsection{Predicting Poverty Headcount: Two-stage Probit Least Squares Model}

Table 4. Predicting Poverty Headcount

\begin{tabular}{|c|c|c|c|c|}
\hline & \multicolumn{2}{|c|}{ Poverty headcount $\left(Z_{P}\right)$ (Probit) } & \multicolumn{2}{|c|}{$\begin{array}{c}\text { Years of Schooling } \\
\text { completed by head }\left(Z_{F}\right)(\text { OLS })\end{array}$} \\
\hline & Rural & Urban & Rural & Urban \\
\hline Years of schooling completed by head $\left(Z_{F}\right)$ (instrument) & $\begin{array}{c}-0.140 * * \\
(0.038)\end{array}$ & $\begin{array}{l}-0.155^{*} \\
(0.039)\end{array}$ & - & - \\
\hline Poverty headcount $\left(Z_{P}\right)$ (instrument) & - & - & $\begin{array}{l}-0.271^{*} \\
(0.133)\end{array}$ & $\begin{array}{l}-1.371 * \\
(0.256)\end{array}$ \\
\hline Years of schooling completed by mothers $\left(X_{M}\right)$ & - & - & $\begin{array}{c}0.425 * * * \\
(0.042)\end{array}$ & $\begin{array}{c}0.070 \\
(0.062)\end{array}$ \\
\hline Household size $\left(X_{S}\right)$ & $\begin{array}{c}0.054 * * * \\
(0.004)\end{array}$ & $\begin{array}{c}0.052 \\
(0.004)\end{array}$ & $\begin{array}{l}0.103 * \\
(0.021)\end{array}$ & $\begin{array}{c}0.214 \\
(0.034)\end{array}$ \\
\hline Right of disposal of land $\left(X_{D}\right)$ & $\begin{array}{c}0.070 * * \\
(0.018)\end{array}$ & $\begin{array}{c}0.009 \\
(0.045)\end{array}$ & - & - \\
\hline age of household head $\left(X_{A}\right)$ & $\begin{array}{c}0.010^{* * *} \\
(0.003)\end{array}$ & $\begin{array}{c}0.003 \\
(0.004)\end{array}$ & $\begin{array}{c}0.009 \\
(0.007)\end{array}$ & $\begin{array}{c}0.014 \\
(0.015)\end{array}$ \\
\hline square of age of household head $\left(X_{A A}\right)$ & $\begin{array}{l}0.000^{*} \\
(0.000)\end{array}$ & $\begin{array}{c}0.000 \\
(0.000)\end{array}$ & $\begin{array}{c}0.000 \\
(0.000)\end{array}$ & $\begin{array}{c}0.000 \\
(0.000)\end{array}$ \\
\hline $\operatorname{Sex}\left(X_{X}\right)$ & - & - & $\begin{array}{c}0.009 \\
(0.044)\end{array}$ & $\begin{array}{c}0.109 \\
(0.100)\end{array}$ \\
\hline Time taken to go to primary school $\left(X_{T}\right)$ & - & - & $\begin{array}{c}-0.001 * * * \\
(0.000)\end{array}$ & $\begin{array}{c}0.002 \\
(0.002)\end{array}$ \\
\hline Geographic Location of the household $\left(X_{R}\right)$ & $\begin{array}{c}0.027 * * \\
(0.015)\end{array}$ & $\begin{array}{l}0.006 \\
0.019\end{array}$ & - & - \\
\hline Public service delivery by local councils $\left(X_{P}\right)$ & $\begin{array}{c}0.023 * * \\
(0.009)\end{array}$ & $\begin{array}{c}0.063 * * \\
0.015\end{array}$ & $\begin{array}{c}0.063^{* *} \\
(0.020)\end{array}$ & $\begin{array}{l}0.211 * \\
(0.093)\end{array}$ \\
\hline Macroeconomic support times council effectiveness $\left(X_{G} * X_{P}\right)$ & $\begin{array}{l}0.028^{*} \\
(0.010)\end{array}$ & $\begin{array}{c}-0.024 * \\
0.012\end{array}$ & $\begin{array}{c}0.002 \\
(0.020)\end{array}$ & $\begin{array}{c}-0.085^{* *} \\
(0.053)\end{array}$ \\
\hline Macroeconomic support (central transfers) $\left(X_{G}\right)$ & $\begin{array}{c}0.010 \\
(0.010)\end{array}$ & $\begin{array}{l}0.016 \\
0.013\end{array}$ & - & - \\
\hline Macroeconomic support times location $\left(X_{G} * X_{R}\right)$ & $\begin{array}{l}-0.015 \\
(0.011)\end{array}$ & $\begin{array}{c}0.025^{* * *} \\
0.012\end{array}$ & - & - \\
\hline Constant & $\begin{array}{l}-0.022 \\
(0.338)\end{array}$ & $\begin{array}{c}0.275 \\
(0.296)\end{array}$ & $\begin{array}{c}1.358^{* *} \\
(0.210)\end{array}$ & $\begin{array}{c}1.143^{* * *} \\
(0.489)\end{array}$ \\
\hline Sample predicted poverty headcount & 0.678 & 0.291 & - & - \\
\hline Sample predicted years of schooling & - & - & 10 & 16 \\
\hline$N$ & 2955 & 2268 & 2955 & 2268 \\
\hline F/LR-Chi-Square & $262(0.00)$ & $387(0.00)$ & $35(0.00)$ & $66(0.00)$ \\
\hline
\end{tabular}

Notes: Reported are marginal probabilities for the probit estimated at the mean values of the regressors. *** denotes significant estimates at 1 percent; ** significance at 5 percent; * denotes significance at 10 percent; standard errors are in parentheses 
In the 2SPSL model, we report predicted marginal probabilities of poverty headcount in the probit component evaluated at the mean values of the regressors, while the OLS component predicts marginal years of schooling of the household head (see Table 4). ${ }^{11}$

At the current average level of schooling in the rural areas, and the rural household size, land distribution pattern, the age of household head, the geographic location of the households, the level of macroeconomic support from central government, and status of public service delivery, the probability of becoming poor in the rural areas is generally estimated at 0.678 . This clearly indicates that the conditions surrounding the rural households are not conducive to welfare improvement. The probability of becoming poor in the urban areas evaluated at the mean of these conditions in that sector is estimated at 0.296 , which is more than two-fold less than the rural estimates. It glaringly suggests a wide development disparity between the rural sector and urban sector. As reflected in the various covariates, all these conditions are significant in affecting rural poverty except for macroeconomic support and its marginal probability with respect to location. The regressors that are not significant in the urban model are the right of disposing land through the market (perhaps because farmland is not an issue there), age, geographic location and macroeconomic support. As in the rural sector, managing macroeconomic support is again coming out as a significant issue depending on the level of effectiveness of the local councils.

Turning to the individual regression coefficients, the marginal probability of reducing poverty headcount for every additional year gained in schooling by the household head is estimated at 0.140 for the rural sector, surpassed by the probability response in the urban areas of 0.155 . This implies out of every 1,000 poor persons in the rural and urban sectors, about 140 and 155 of them are expected to be bailed out of poverty respectively for every additional year gained in the head's schooling. The mean elasticities of poverty reduction are estimated at 0.56 percent for the rural areas (inelastic response) and 2.06 percent for the urban areas (elastic response) for every percentage increase in the number of years the head spends schooling. As presented below, since the average household in the urban area is predicted to have a higher level of education attainment than the rural counterpart, a small increase in the number of years in school in the urban sector would increase job access chances there more than the rural counterpart.

It is counterintuitive but explainable that the right of disposing land through the market in the rural areas increases the chances of holders becoming poor, although at a small probability of 0.07 , with inelastic coefficient of 0.051 . It suggests there would be upward pressure on poverty in the absence of proper negotiations over land sales on behalf of the peasant most of whom lack education; also, poverty would not be stemmed effectively if proceeds from land

11Coefficients estimates of the 2SPLS model omitted here to save space can be obtainable from the authors upon request. sales are not put into proper use.

The effect of age is partly as expected (on its polynomial covariate end) and partly not (on the linear end). It is expected to reduce poverty over the early age range (the early years, which is the linear covariate part, moving from childhood to adulthood with expected increase in one's economic activity); in the late age range, poverty increase cannot be unexpected (the polynomial covariate end) where one retires or becomes less economically active, if especially sufficient inter-temporal budget planning had not been done through savings and investment for old age.

The data suggest that, scoring local councils high for public service delivery under the current assessment framework does not appear to necessarily imply reduced household poverty as its positive marginal coefficient estimates both for rural sector $(0.023)$ and urban sector (0.063) indicate. This could suggest the need for better framework for service delivery performance assessment. Another implication, however, is that the initial (short run) effort in service delivery might not be Pareto effective although indeed the welfare of some segments of the population may have increased. That is, if the growth in poverty of the (possibly) left out populations outweighs the positive effect of service delivery on a small population the net increasing effect on poverty cannot be unexpected. The net negative welfare effect can, however, be minimised or eliminated overtime, in that there is indirect reducing poverty effect of service delivery through increased education of the head estimated at -0.009 for rural sector and -0.033 for urban, although not sufficient to produce the desired net negative effect.

In addition to other regressors analysed in the OLS component, poverty headcount is also found to significantly impact on the head's schooling - the two endogenous variables affect each other. The average number of years spent in school among rural households is estimated at 10 (about completing primary level) while years completed among urban households are estimated at about 16 (about finishing junior level) putting the urban sector in a position to earn from education better than the rural sector.

However, it appears the cost of poverty is higher in the urban sector, where years of schooling more than reduce at a rate of 1.371 for every person falling into poverty relative to the rural sector at 0.271 . In other words, the poor in the urban areas are more likely to lose in schooling relative to the nonpoor by 1.371 years, than it is for the poor in the rural areas. This has an indirect increasing feedback effect on poverty headcount, forcing 37 out of every 1,000 persons to fall into poverty in the rural areas, and 212 out of every 1,000 persons to fall into poverty in the urban areas, a transmission and spiral effect triggered by someone initially slipping into poverty.

Increasing spouse education and management of household size are found significant with expected signs in influencing rural household education, but not significant in the urban areas. Age and sex are not significant in affecting 
education in the two sectors. Time taken to access primary school (controlling for effects of community infrastructure on welfare) comes out significant in influencing schooling in the rural areas; suggesting that school attendance increases with decrease in time spent to access school through increased supply of school structures in the communities; the coefficient does not come out significant for the urban areas perhaps because the urban areas are generally far more favoured in the provision of schooling facilities than the rural areas and thus time would not be as much of an issue. Macroeconomic support comes out significant in affecting schooling but conditioned on how effective the local councils are in managing resources, but significant only for the urban areas.

\subsection{Minimum Financial Resources Needed to Close Poverty Gap}

We use the regression estimates of the 2SPLS model to estimate the financial resources needed to close the poverty gap in the rural and urban areas, with special focus on the share of these resources needed in education and other policy choice areas in the process. The model estimates a rural poverty headcount ratio or probability of 67.8 percent compared to 29.10 percent for urban areas. Based on the current national poverty line of Le $1,587,746$ (US\$ 363) ${ }^{12}$ and rural and urban populations of 3.5 million and 2.3 million respectively, the predicted minimum resources necessary to close the poverty gaps in the two sectors are estimated at USD 223 million and USD 25 million respectively (See Table 5).

Table 5. Financial Resources Required to Close Rural Poverty Gap

\begin{tabular}{cccc}
\hline Policy Areas & $\begin{array}{c}\text { Predicted } \\
\text { probability } \\
\text { of reducing poverty } \\
\text { headcount (Po) }\end{array}$ & $\begin{array}{c}\text { Predicted } \\
\text { Resal Gap } \\
\text { Needed for } \\
\text { Eradication } \\
\text { of Rural } \\
\text { Poverty }\end{array}$ & $\begin{array}{c}\text { Minimum } \\
\text { Investment } \\
\text { Needed Per } \\
\text { policy } \\
\text { Areas }\end{array}$ \\
\hline Education & 0.140 & & 31 \\
\hline $\begin{array}{c}\text { Rural } \\
\text { Population } \\
\text { Planning }\end{array}$ & 0.054 & & 12 \\
\hline Land Reform & 0.070 & 223 & 16 \\
\hline $\begin{array}{c}\text { Local council } \\
\text { capacity } \\
\text { building }\end{array}$ & 0.075 & & 148 \\
\hline Others & 0.665 & & 17 \\
\hline
\end{tabular}

Notes: Resources and investment needed are in US million dollars.

Predicted probabilities are based on estimates from the probit model, $\mathrm{Zp}$, in Table 4.

Of the predicted resources by the 2SPLS model, 14 percent (probability of reducing poverty through schooling) are suggested necessary to be invested in education towards closing the poverty gap in the rural sector in the coming

12 See World Bank (2013) and Bangura (2015) on the poverty profile for Sierra Leone. fiscal years, amounting to a minimum of USD 31 million. ${ }^{13}$ This estimate is USD 3.8 million for the urban area at a share of 15.5 percent (marginal probability of reducing poverty ratio by an additional year of schooling in the urban area). Those suggested for investment in rural population planning, land reform, and building public service delivery capacity (including macroeconomic support) are estimated at USD 12 million, USD 16 million and USD 17 million, based on predicted marginal probabilities of $0.054,0.070$, and 0.075 , respectively (Table 6 for investment requirements). In the urban areas the amount estimated for investment in strengthening public service delivery capacity (including macroeconomic support) is USD 2.8 million. We do not estimate for land reform and population planning for the urban areas since the related policy variable is not found significant in the model for urban areas.

\section{Concluding Remarks}

This study has discovered education as a lead predictor of poverty at all levels, suggesting that the state should devote a substantial share of national budget towards education investment in Sierra Leone in particular, and Africa in general. Reversibly, poverty itself is found to have a substantial impact on education with enormous feedback effect - spiral and self-reinforcing effect. Health is a critical component of human capital within which framework the nexus between education and poverty has been analysed; it is a key dimension of poverty as education and income consumption variables analysed, the three of which have been discovered in this paper to affect each other. Evidence suggests that even if policies were currently perceived effective, they could have negative direct impact on welfare in the immediate or short run; but could have the desired long run effect such as discovered by the indirect effect of the covariates traced through intermediary factors, coming out positive in a number of estimation instances. This lends credence to the estimation approach adopted for this analysis - a system framework - than sector by sector or equation by equation framework to reveal direct and indirect interaction of variables.

The evidence culled from this paper suggests policy trade-offs are inevitable, more so in the short-run. Suggestively, for instance, a prevailing negative welfare

13The minimum resources needed to invest in education towards closing the poverty gap is an expected value calculated by multiplying the predicted marginal probability of reducing poverty headcount through schooling by the predicted total amount of minimum resources needed to close the poverty gap: that is, $0.140 *$ USD223 million. This applies to other policy choice areas analyzed. The USD223 million is obtained as follows: (i) based on the predicted probability of becoming poor of 0.678 (see Table 4), and a total rural population of $3,500,000$, the estimated rural poverty population is $0.678 * 3,500,000=2,373,000$; (ii) given the national poverty line of Le1,587,746 and rural poverty gap of 25.9 percent (see Bangura 2015, pp.230-234), the minimum resources required to lift each poor person out of poverty is estimated at Le411,226.21; (iii) thus, the total amount of resources required to lift the entire poor population out of poverty is Le $411,226.21 * 2,373,000=\mathrm{Le} 975,839,805,822$; and (iv) therefore, the US Dollar equivalent resources required to lift the entire poor population out of poverty at exchange rate of Le4,375/USD in 2011 is Le975,839,805,822/Le4,375=USD223 million. 
effect amidst highly rated service delivery performance could stem from the fact that: (i) indeed policies could have positively affected certain segments of the population; but (ii) there may have been some negative redistributive and allocative effects on other segments during implementation that may outweigh the current positive effect. This, on the whole calls for careful management of policies to reconcile possible short run negative impacts with desired long run effects, or such that the net short run effect is positive. There is further implication of the need to always carefully assess needs, weighing the needs of one location or socio-economic group relative to another, possibly with the help of constructing differential disadvantage index as part of a broader targeting framework process; implementing a robust monitoring framework in the service delivery process can be hugely crucial.

It is noted on average that education pays off more highly in the urban areas than in the rural areas given the wide differentials in the predicted poverty elasticity response to average years spent in school in the rural and urban areas. Any additional year in school in the urban areas could take the households there higher in knowledge acquisition with more chances of securing high paying labour market jobs than an additional year would in the rural areas. Presently, the average level of schooling of the average rural household is far below the urban counterpart. Coupled with the relatively poor infrastructure in the rural areas, this could further explain why the rural sector's inelastic response of poverty headcount to education.

The paper does note the potential that exists for some policies to impact on the rural areas much faster than in the urban areas such as direct income support, especially as the 3SLS suggests. However, on the whole, from a benefit incidence perspective, the estimates suggests public policy has been somewhat more pro-urban than rural, and hence not as pro-poor as could have been desired, evincing a need for recalibration of policies towards a more balanced development and need-based response, especial from the point of view of education resources distribution, education being the most critical element for poverty reduction (Demery 2000).

Because of the generally high cost of living in the urban areas relative to the rural areas, it is suggested here that the cost of poverty (any marginal reduction in income) is much more poverty increasing in urban Sierra Leone than the country's rural areas with a disproportionate reinforcing poverty adding effect in the former than the latter. These evoke the vulnerability dimension of poverty and the need for classifying populations into those deemed currently poor and those that are at high risk of becoming poor (the vulnerable) in policy analysis and formulation. Various papers have advocated the need for this classification to forestall unexpected ballooning of poverty caseloads in the future, from a stock and flow variable analytical perspective of poverty (Oni and Yusuf 2008). While the poor, especially those in extreme state, could already have been vulnerable, there could be segments currently on or above the poverty line that are associated with riskier factors that should be identified and prevented from slipping into poverty in the near future; such groups are common in the urban peripheries, slums, bays, and so on. Policy should therefore be holistic, ensuring adequate coverage of poverty pockets and vulnerability in the urban as well as rural areas. Another implication and recommendation culled from evidence here is the need for effective population management along any policy implemented including education.

This study has effectively analysed the nexus between education and poverty with evidence from Sierra Leone. It is instructive from this analysis in support of others that the determinants of poverty for which education is one of the dimensions can be understood best if a system analytical approach is followed than undertaking single equations analysis. It is critical in poverty analysis that both direct and indirect effects of variables be traced to better inform policy. The system approach employed in this paper has revealed that policies have transmission channel through which they affect welfare, and indeed in the short run policies may appear negative in influencing development but could yield desired effects overtime. Generally, education is critical for poverty reduction but requires enormous resources to investment in its promotion especially in the rural areas if poverty should be reduced more effectively. There are structural bottlenecks that inhibit provision of education services in the rural areas including bad geographic terrains and road conditions that require transformation, as well as population planning, and strengthening of capacity for public service delivery.

\section{REFERENCES}

[1] Aguayo, V., S. Scott, and J. Ross (2003), "Sierra Leone-Investing in Nutrition to Reduce Poverty: A Call for Action," Public Health Nutrition, 6(7): 653-657.

[2] Acker, D., and L. Gasperini (2003), "Launching a New Flagship on Education for Rural People: An Initiative Agricultural and Extension Educators Can Get Behind," Journal of International Agricultural and Extension Education, 10(3): 81-85.

[3] Bangura, S. 2015. Rural Household Poverty in Post-conflict Sierra Leone: Understanding Entrenched Deprivations in the Global South. Lambert Academic Publishing; Germany. February 2015

[4] Banya, K. (1993), "Illiteracy, Colonial Legacy and Education: The Case of Modern Sierra Leone," Comparative Education, 29(2): 159-170.

[5] Becker, G.S. (1960), “An Economic Analysis of Fertility,” in G.S. Becker (ed.), Demographic and Economic Change in Developed Countries, Princeton University Press, Princeton, NJ.

[6] Black, S.E., P.J. Devereux, and K.G. Salvanes (2005), "The More the Merrier? The Effect of Family Size and Birth Order on Children's Education," Quarterly Journal of Economics, 120(2): 669-700. 
[7] Chen. S., and M. Ravallion (2008), "The Developing World is Poorer Than We Thought, But No Less Successful in the Fight against Poverty," World Bank Policy Research Working Paper No. 4703.

[8] Chenery, H. (1979), Structural Change and Development Policy, New York: Oxford University Press.

[9] Colleir, P. (2007), The Bottom Billion: Why the Poorest Countries Are Failing and What Can Be Done about It, Oxford University Press.

[10] Deaton, A. and S. Zaidi (2002), "A Guide to Aggregating Consumption Expenditures, Living Standards Measurement Study," Working Paper 135, World Bank.

[11] Demery, L. (2000), Benefit Incidence: A Practitioner's Guide, Poverty and Social Development Group. Africa Region, World Bank.

[12] Domar, E. (1947), "Expansion and Employment," American Economic Review, 37(1): 34-55.

[13] Government of Sierra Leone (2010), National Education Policy 2010, Ministry of Education, Science, and Technology. Freetown, Sierra Leone.

[14] Griliches, Z., and Mason, W.M. (1972), "Education, Income, and Ability," Journal of Political Economy, 80(3): S74-S103.

[15] Grossman, M. (2000), "The Human Capital Model," Handbook of Health Economics, Volume 1, in A.J. Culyer and J.P Newhouse (eds.), Elsevier Science B.V.

[16] Grossman, M., and R. Kaestner (1997), "Effects of Education on Health," in J.R. Behrman and N. Stacey (eds.), The Social Benefits of Education, University of Michigan Press, Ann Arbor, MI, USA, 69-123.

[17] Hanlon, J. (2005), "Is the International Community Helping to Recreate the Preconditions for War in Sierra Leone?" United Nations University, UNU-WIDER. Research Papers. No. $2005 / 50$.

[18] Harrod, R. (1948), Towards a Dynamic Economics: Some Recent Developments of Economic Theory and Their Application to Policy, London, Macmillan.

[19] Heckman. J.J., L.J. Lochner, and P.E. Todd (2003), "Fifty Years of Mincer Earnings Regressions," University of Rochester, Rochester, NY.

[20] Kasirye, I., S. Ssewanyana, J. Nabyonga, and D. Lawson (2004), "Demand for Health Care services in Uganda: Implication for Poverty Reduction,” MPRA Paper 8558, University Library of Munich, Germany.

[21] Kenkel, D.S. (1991), "Health Behavior, Health Knowledge, and Schooling," Journal of Political Economy, 99(2): 287-305.

[22] Koning, R. De. (2008), "Resource-Conflict Links in Sierra Leone and The Democratic Republic of the Congo," SIPRI Insight on Peace and Security, No.2008/2, Stockholm International Peace Research Institute.

[23] Lewis, W. A. (1954), "Economic Development with Unlimited Supplies of Labor," Manchester School, 22(2): 139-191.
[24] Lindelow, M. (2003), "The Utilisation of Curative Health Care in Mozambique: Does Income Matter?" Centre for Study of African Economies, Oxford University.

[25] Mackinnon, J. (1995), "Health As an Informational Good: The Determinants of Child Nutrition and Mortality during Political and Economic Recovery in Uganda," The Centre for the Study of African Economies Working Paper Series, Centre for the Study of African Economies, University of Oxford.

[26] Mincer, J. (1958), "Investment in Human Capital and Personal Income Distribution," Journal of Political Economy, 66 (4): 281-302.

[27] Mincer, J. (1974), Schooling, Experience, and Earnings, Columbia University Press for the National Bureau of Economic Research, New York.

[28] Moyo, D. (2009), Dead Aid: Why Aid Is Not Working and How There is Another Way for Africa, Farrar, Straus and Giroux, New York.

[29] Oni, O.A. and Yusuf, S.A. (2008), "Determinants of Expected Poverty Among Rural Households in Nigeria," Research Paper 183, African Economic Research Consortium.

[30] Otsuka, k., J.P. Estudillo, and Y. Sawada (2009a), “Towards a New Paradigm of Farm and Nonfarm Linkage in Economic Development," in Otsuka, K., J. P. Estudillo, and Y. Sawada (eds.), Rural Poverty and Income Dynamics in Asia and Africa, Routledge, London.

[31] Otsuka, K., J. P. Estudillo, and Y. Sawada (eds.), (2009b), Rural Poverty and Income Dynamics in Asia and Africa, Routledge, London.

[32] Puddington, A. (2010), "Freedom in the World 2010: Erosion of Freedom Intensifies,". Freedom House.

[33] Romer, P.M. (1992), "Two Strategies for Economic Development: Using Ideas and Producing Ideas," Proceedings of the World Bank Annual Conference on Development Economics, 1992. Supplement, World Bank Economic Review and The World Bank Research Observer, 63-91.

[34] Romer, P.M. (1993), "Implementing a National Technology Strategy with Self-Organizing Industry Investment Boards," Brookings Papers on Economic Activity 2: 345-390.

[35] Rostow, W. (1960), The Stages of Economic Growth, Cambridge, UK: Cambridge University Press.

[36] Sachs, J. (2005), The End of Poverty. How We Can Make It Happen in Our Lifetime, Penguin Books.

[37] Sachs, J. and Warner, A. (2001), "The Curse of Natural Resources," European Economic Review, 45(4-6): 827-838.

[38] Sahn, D.E. and Stifel, D. (2003), "Exploring Alternative Measures of Welfare in the Absence of Expenditure Data," Review of Income and Wealth Series, 49(4); 463-489.

[39] Sen, A, K, (1993), "Capability and Well-Being," in A. Sen and M. Nussbaum (eds.), The Quality of Life, 30-53, Helsinki, Finland, United Nations University.

[40] Shaffer, P. (2008), "New Thinking on Poverty: Implications for Globalization and Poverty Reduction Strategies." DESA Working Paper, 28, United Nations Department of Economic and Social Affairs. 
[41] Solow, R.M. (1956), "A contribution to the theory of economic growth," Quarterly Journal of Economics, 70(1): 65-94.

[42] United Nations Development Programme (2010), Human Development Report, The United Nations.

[43] Walraven, G. (2011), "Health and Poverty," Global Health Problems and Solutions, Earthscan Ltd, London, 109-121.

[44] Wagle, U. (2010), Multidimensional Poverty Measurement: Concepts and Applications (Economic Studies in Inequality, Social Exclusion and Well-Being), Springer, New York.

[45] Whiteside, A., C. Andrade, L. Arrehag, S. Dlamini, T.
Ginindza, and A. Parikh (2006), "The Socio-Economic Impact of HIV/AIDS in Swaziland," National Emergency Response Council on HIV/AIDS, Mbabane, Swaziland.

[46] World Bank (1981), "World Levels of Literacy," Third World Quarterly, 3(3): 532-533+537.

[47] World Bank (2008), Sierra Leone Poverty Diagnostic, Poverty Reduction and Economic Management Sector Unit Sub-Saharan Africa Region, World Bank. Washington DC, USA.

[48] World Bank (2013), A Poverty Profile for Sierra Leone, The World Bank Poverty Reduction and Economic Management Unit, Africa Region, World Bank, Washington DC, USA. 